\title{
The Freedom SOLO bovine pericardial stentless valve
}

\author{
This article was published in the following Dove Press journal: \\ Research Reports in Clinical Cardiology \\ 2 December 2014 \\ Number of times this article has been viewed
}

\author{
Olaf Stanger \\ Hendrik Tevaearai \\ Thierry Carrel \\ Clinic for Cardiovascular \\ Surgery, University Hospital \\ Berne, Switzerland
}

Correspondence: Thierry Carrel

Clinic for Cardiovascular Surgery,

University Hospital, $\mathrm{CH}-30 \mathrm{IO}$ Berne,

Switzerland

Tel +4I 3I 6322375

Fax +4I 3I 6324443

Email thierry.carrel@insel.ch
Abstract: The third-generation bovine pericardium Freedom SOLO (FS) stentless valve emerged in 2004 as a modified version of the Pericarbon Freedom stentless valve and as a very attractive alternative to stented bioprostheses. The design, choice of tissue, and anticalcification treatment fulfill most, if not all, requirements for an ideal valve substitute. The FS combines the singlesuture, subcoronary implantation technique with the latest-generation bovine pericardial tissue and novel anticalcification treatment. The design allows imitation of the native healthy valve through unrestricted adaption to the patient's anatomy, reproducing a normal valve/root complex. However, despite hemodynamic performance superior to stented valves, we are approaching a critical observation period as superior durability, freedom from structural valve deterioration, and nonstructural failure has not been proven as expected. However, optimal performance and freedom from structural valve deterioration depend on correct sizing and perfect symmetric implantation, to ensure low leaflet stress. Any malpositioning can lead to tissue fatigue over time. Furthermore, the potential for better outcomes depends on optimal patient selection and observance of the limitations for the use of stentless valves, particularly for the FS. Clearly, stentless valve implantation techniques are less reproducible and standardized, and require surgeondependent experience and skill. Regardless of whether or not stentless valve durability surpasses third-generation stented bioprostheses, they will continue to play a role in the surgical repertoire. This review intends to help practitioners avoid pitfalls, observe limitations, and improve patient selection for optimal long-term outcome with the attractive FS stentless valve.

Keywords: aortic valve, bioprosthesis, cardiac surgery, aortic valve replacement, tissue valve, stentless aortic valve, hemodynamics, long-term results

\section{Background}

Aortic valve prostheses have evolved considerably over the last 50 years, especially with respect to technical aspects, such as design, implantation technique, and processing. Treatment of aortic valve pathologies with valve prostheses began with the use of cage-ball valves in the descending aorta of patients with aortic regurgitation. ${ }^{1}$ This was followed by subcoronary aortic valve replacement (AVR) using aortic allografts (homografts), 2,3 and mechanical cage-ball and "monostrut" models in the 1960s. ${ }^{4}$ Interestingly, homografts mounted on a stented frame were used as early as in 1965, to simplify implantation techniques; however, these stents caused tissue failure within a few years and as such, were less durable than freehand-sewn homografts and were subsequently abandoned. ${ }^{5}$

Stent-mounted porcine xenograft valves, first implanted in 1964 and 1965, ${ }^{6,7}$ were treated with mercurial solution and formaldehyde ${ }^{8}$ in order to arrest autolysis and fix tissue, but this treatment also caused shrinkage and stiffness. The introduction 
of glutaraldehyde (GA) fixation ${ }^{9}$ represents the next major advance and is still used today for all bioprostheses. However, the high rate of early mechanical failure with first-generation stented porcine xenografts ${ }^{10}$ soon became obvious, particularly in younger patients and thus stimulated work to improve preservation, biocompatibility, design, and valve mounting strategies. $^{11}$

Conceptually, the ideal valve substitute has remained largely unchanged ${ }^{12}$ and includes unobstructed central flow, maximum effective orifice area (EOA) with low transvalvular gradients, low thrombogenicity, prolonged durability, easy implantability, resistance to infection, and freedom from anticoagulation. ${ }^{13}$ However, still today, no single prosthesis fulfils all of these criteria. Widespread use of homografts is limited by the practical problems of restricted availability of different sized specimens, demanding techniques, and questionable long-term outcomes, while mechanical valves still require lifelong anticoagulation with the potential of undesirable secondary events. Following the observation of significantly lower valve leaflet deterioration in homografts compared with (first-generation) stented xenografts, ${ }^{14}$ the stentless valve concept was proposed to combine the advantages of both homografts (nonobstructive EOA) and stented bioprostheses (unlimited availability). Furthermore, a flexible aortic root was believed to be essential for natural leaflet stress distribution; thus, implantation of an unstented xenograft with minimal disruption of aortic root dynamics was expected to reduce dynamic stress on leaflets, thereby translating into a lower probability of structural valve deterioration (SVD). ${ }^{15}$ In addition, the importance of left ventricular (LV) mass was identified in the Framingham Heart Study, ${ }^{16}$ and complete regression of $\mathrm{LV}$ hypertrophy $(\mathrm{LVH})$ was defined as a major prognostic factor determining late outcome after AVR. ${ }^{17}$ Importantly, the stentless design was expected to better permit regression as a result of superior hemodynamics due to lower gradients in the absence of obstructive stents.

The current review describes the Freedom SOLO (FS) stentless valve (Sorin Biomedica, Saluggia, Italy), a valve that was introduced in our teaching institution in 2004 because the implantation was thought to be easy and hemodynamic performance was expected to be favorable.

\section{Evolution of the FS stentless valve}

The FS is directly derived from the Pericarbon Freedom (PF) stentless (Sorin Biomedica), which has been available since 1991. ${ }^{18}$ Cusp shaping and tissue fixation of the PF is obtained with a fluidic process that uses increasing GA concentrations (up to $0.5 \%$ ) in phosphate buffer at $\mathrm{pH} 7.4$ under low pressure. ${ }^{19}$ The PF was redesigned in 2000 with the addition of a posttreatment step using homocysteic acid (HCA) in order to remove aldehyde residues, as further discussed below. The resulting two-sheet structure is composed of an external scalloped cylinder containing an internal cylinder in the form of three valvular cusps, and the inflow rim. This design avoids the stitches becoming points of excessive stress concentration - where fatigue fracture lines would eventually originate - particularly, in the commissural areas. ${ }^{18}$ The PF bioprosthesis is provided by the manufacturer with extra tissue, allowing intraoperative tailoring for adaptation to the patient's specific anatomy and the surgeon's technique, and is implanted with two suture lines (Figure 1A).

The FS bovine pericardial aortic valve emerged in May 2004 as a modified version of the PF valve (Figure 1B). The design modification that resulted in the FS was aimed at allowing subcoronary, supra-annular implantation with only one suture line, achieved through the trimming of all extra tissue from the PF valve inflow side, and the scalloping of the outflow side to preserve the valve assembly suture. ${ }^{20}$ As such, the FS combines the latest-generation bovine pericardial tissue and novel anticalcification treatment, with the singlesuture, subcoronary implantation technique first applied by O'Brien to porcine stentless valves. ${ }^{21}$ This design allows imitation of the native healthy valve through unrestricted adaption to each individual patient's anatomy.

Finally, the prosthesis holder was recently replaced with a short metal stent holder for easier handling (Figure 1C), indicated by the addition of "Smart" to the valve's name.

\section{Implantation technique of the FS: tips and pitfalls}

When the implantation of a FS stentless valve is planned, a transverse aortotomy should be performed high above the commissures, in order to provide good vision over the sinuses as well as sufficient space for FS commissure attachment to the aortic wall. Three reference "stay" sutures placed slightly above the commissures are helpful. Particular attention must be paid to the aortic root anatomy, and a correct sizing is critical. Symmetric implantation may be difficult with a
A

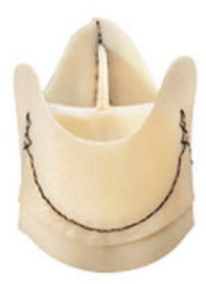

B

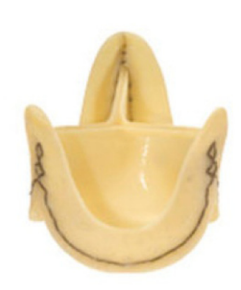

C

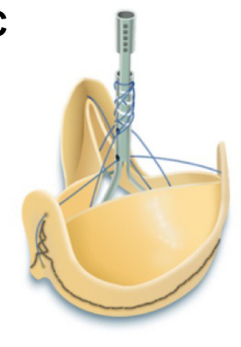

Figure I Pericarbon Freedom (A), Freedom SOLO (B), and SOLO Smart (C). 
wide and deep noncoronary (NC) sinus and particularly in the case of bicuspid aortic valve (BAV), when the commissure landmark is missing. We therefore discourage use of a stentless valve in a BAV root anatomy. There is also a potential risk of regurgitation over time, due to presumed coexistent aortic disease and potentially later aortic dilatation in these patients. The use of FS should therefore be avoided in patients with BAV and in those with moderate dilatation of the ascending aorta. The fundamental importance of accurate sizing and prosthesis selection must be emphasized. The probe should tightly fit the aortic annulus (Figure 2A). The prosthetic valve corresponding to the probe is already upsized by the manufacturer, to one size more or $2 \mathrm{~mm}$ larger than the annular diameter. When in doubt with determining the correct valve size, one should consider that oversizing the FS may result in S-shaped leaflet folding with functional stenosis and high gradients. ${ }^{22}$ Another source of dysfunction can be the presence or likelihood of future root and/or sinotubular junction dilatation, which have the potential to cause regurgitation. ${ }^{23}$ This means that both oversizing and undersizing have the potential to cause prosthesis failure. In general, if one size is too small and the larger one fits the annulus with some resistance, the larger one should be implanted. ${ }^{24}$

Three equidistant, intercommissural sutures (polypropylene 4-0, using a small taper-cut semicircular needle) are then placed in the supra-annular position at the nadir of each sinus, at 2-3 $\mathrm{mm}$ above the native annulus. Each of these sutures must be placed at the corresponding part of the tissue valve cusps, using the pericardial strip available at the basis of the stentless valve (Figure 2B). Placement of sutures
A
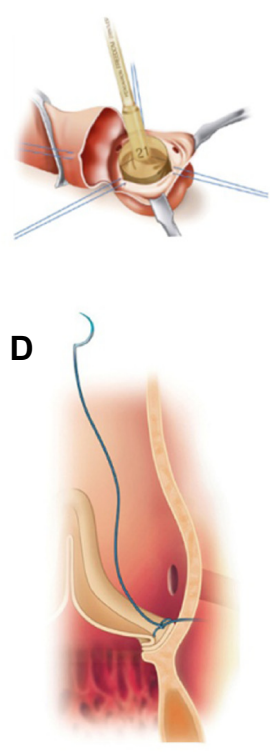

G

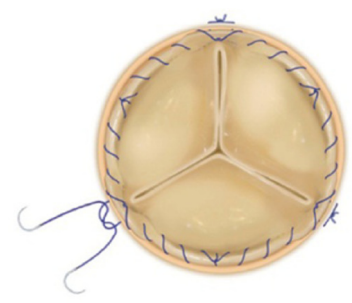

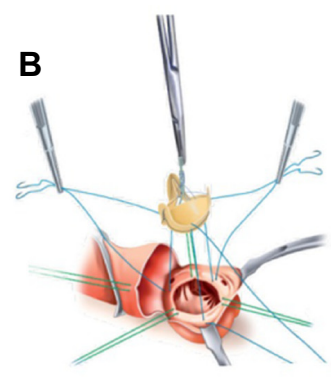

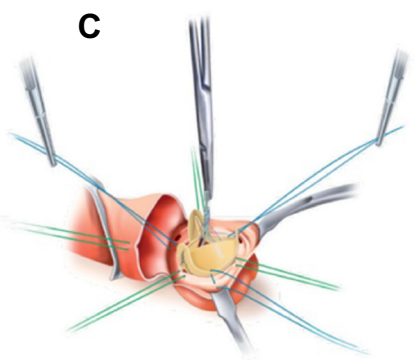

E
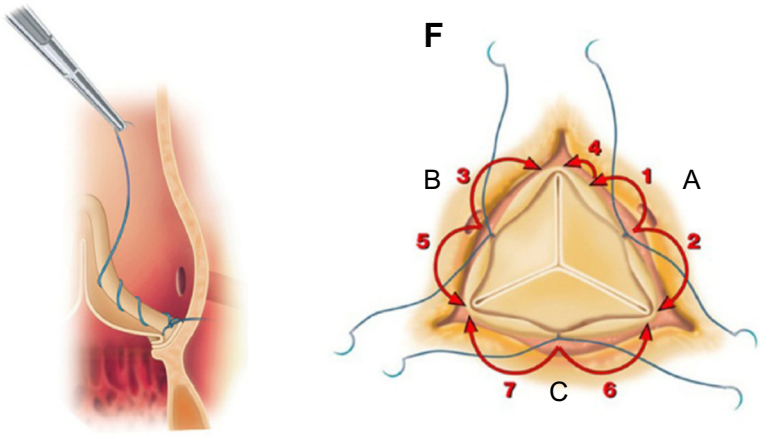

H

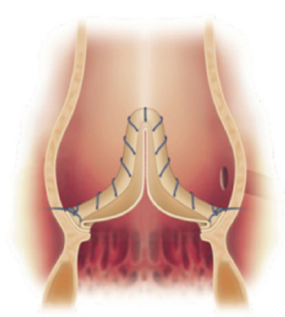

I

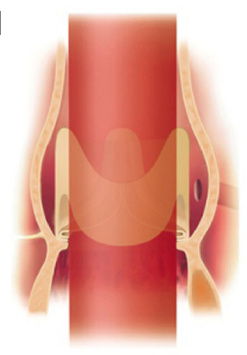

Figure 2 Implantation technique of the Freedom SOLO stentless valve.

Notes: (A) Transverse aortotomy, 3 string sutures at the level of the commissures and sizing. (B) The first three stitches are passed at the nadir of each sinus and through the pericardial rim of the tissue valve. (C) The valve is parachuted down into the aortic anulus. (D) The first stitch is demonstrated at the nadir of the sinus. (E) The continuous suture is performed in direction of the commissure. (F) This picture demonstrates the sequence of suturing the tissue valve. Starting below the right coronary artery and moving to both commissures (I, 2, and 4) then below the left coronary artery ( 3 and 5$)$ and finally suturing the non-coronary leaflet at the end (6 and 7). A, right-coronary cusp; B, left-coronary cusp; C, non-coronary cusp. (G) Tying of the sutures is performed outside the aorta at the level of the three commissures. (H) Final view of the supraanular, subcoronary continuous suture line from inside the aorta. (I) Final view from outside the aorta with demonstration of a maximized central and homogeneous flow through the valve. 
below or through the annulus must be avoided. At the level of the commissures, the sutures are passed out of the aorta and tied together (Figure 2C-E). At the end of the suturing process, the FS becomes somewhat fixed in the aortic root and the exposition may be more difficult, potentially making suturing difficult, especially in cases with small valve sizes. It is important to avoid too small suture bites, to prevent dehiscence. Care must be taken to avoid any laceration of the valve leaflets with a needle tip and also to prevent any damage of the assembly suture of the valve. Some surgeons have suggested to start suturing at the right coronary sinus, followed by the left coronary sinus, and finally the NC sinus, ${ }^{20}$ but in fact, any order can be followed ${ }^{25}$ (Figure 2F). There is large individual variability in root anatomy, and the $\mathrm{NC}$ sinus often presents wider and deeper than the symmetric prosthesis. Therefore, the suture line can be longer, and consequently, relatively less valve tissue might be available for a longer distance between commissures, resulting in bites that create folding or tension. ${ }^{25}$ In fact, most reported failures and thrombosis were thought to be associated with the NC cusp. ${ }^{26,27}$ In the NC sinus, the suturing plane should be intentionally elevated by $1-2 \mathrm{~mm}$, but care must be taken to follow the annular line (and not to create a straight line). It was also suggested to begin suturing the NC sinus by applying only the first 2-3 stitches on each side, in order to assure tension-free seating of the prosthesis on a nonwrinkled aortic sinus under perfect exposure, and then to continue with the right and left sinus, and finally complete the NC sinus suture line. ${ }^{25}$ In our opinion, the key is to perform correct and tension-free sutures comfortably, regardless of the sequence. We have made it routine to check for folding and leaks with a small instrument (nerve hook). Additional stitches to correct for folding or suspected leaks can be made through the prosthesis and with the knot tied outside the aorta.

\section{Postoperative anticoagulation management}

According to our patient management protocol, if there is no bleeding, patients receive intravenous unfractionated heparin to obtain a partial thromboplastin time of 60 seconds. Heparin was replaced with subcutaneous weight-adapted enoxaparin on the second or third postoperative day. Because of reported FSassociated thrombocytopenia, platelet numbers were recorded daily during the hospital stay. Usually after the fourth postoperative day and following mobilization of the patient, antiplatelet therapy, with acetylsalicylate $100 \mathrm{mg}$ daily, is instituted. As standard protocol, only patients with preoperative cardiomyopathy, chronic atrial fibrillation, or peripheral occlusive vascular disease continued with warfarin $\left(\right.$ Marcoumar $\left.^{\circledR}\right)$. Patients who have isolated AVR combined with coronary artery bypass grafting $(\mathrm{CABG})$ continued with acetylsalicylate only.

\section{Tissue fixation and anticalcification treatment}

All biological tissue valves undergo chemical fixation with GA to provide mechanical stability; this is at the expense of greater susceptibility to calcification, via increases in calcium binding sites, namely, GA residues and phospholipid debris. ${ }^{28}$ In an exclusive treatment, Sorin uses HCA, which features strong electronegative sulfonic groups as postfixation treatment and which cross-links GA to neutralize the free toxic aldehyde groups. ${ }^{20,29}$ The valve is stored in paraben (antimycotic) solution and yields a ready-to-use prosthetic valve that does not require rinsing prior to implantation. The detoxification efficacy is tested by measuring free aldehyde groups and by in vitro cultivation of human endothelial cells on pericardial samples. Detoxified samples (with HCA) showed negligible GA residues and improved endothelial cells proliferation compared with conventionally treated samples, whereas tissue fatigue behavior was not modified by HCA treatment. ${ }^{19}$ Mineralization is usually tested through subcutaneous or intramuscular implantation of valve tissue into animals (rats or rabbits) with determination of calcification, after explantation, using light transmission and scanning electron microscopy as well as atomic absorption spectroscopy. In the subcutaneous rat model, GA-HCA-treated bovine pericardium showed less calcification than did GA alone, after explantation (performed between days 14-84). ${ }^{29}$ However, the effectiveness of this testing has been questioned because this model ignores mechanical and dynamic stress as well as blood-surface contact. ${ }^{30}$ In fact, results from the subcutaneous rat model are completely opposite to those obtained in blood pulsatile models, thereby emphasizing the necessity of blood contact in preclinical valve testing. ${ }^{30}$

\section{Patient selection}

The ideal patient for FS tissue valve implantation is older than 65 years, and has a symmetric aortic root and a trileaflet valve-sinus anatomy. Younger and active patients wishing to avoid anticoagulation and a mechanical valve, and those for whom a homograft is not available may also be candidates. In addition, the FS stentless valve is a very attractive alternative prosthesis for patients with active endocarditis. The supra-annular fixation spares impaired subannular inflammatory tissue and septal abscesses. Indeed, stentless valve prostheses were found to be associated with low reinfection rates and excellent hemodynamic performance comparable with cryopreserved homografts. ${ }^{31}$ Patients with BAV must 
be considered unsuitable because of the missing commissure landmark and coexisting aortic wall pathology, which may cause subsequent sinotubular junction dilatation and potentially lead to regurgitation. Although the FS valve provides some tolerance to mismatch between the annulus and sinotubular junction because of a large coaptation surface, ${ }^{22}$ implantation of the FS should be restricted in enlarged aortas. Massive calcification of the aortic sinus wall and root are also incompatible with FS use as in this case, supra-annular suturing becomes impossible. ${ }^{19}$

\section{Results and experiences Operating time and learning curve}

The first author has collected the FS experience at two institutions (University Hospital, [Berne, Switzerland] and University Hospital Salzburg [Salzburg, Austria]); therefore the combined numbers are reported here. Data on patient characteristics, procedures, outcome, and complications are presented in Tables 1 and 2. In total, 423 AVR procedures with the FS were performed by ten different surgeons, six of whom completed $>20$ procedures (range: $23-152$ ). The mean extracorporeal circulation (ECC) and cross-clamp times were, respectively, $89 \pm 29$ minutes ( $64 \pm 21$ minutes) for isolated procedures and $123 \pm 43$ ( $87 \pm 29$ minutes) for combined procedures, with no significant differences among valve sizes 21 , 23,25 , and 27 . The indications were aortic stenosis $(80.2 \%)$, regurgitation (4.0\%), and combined pathologies (15.8\%). Fourteen patients were operated for active endocarditis.

The median ECC and cross-clamp times decreased, on average, by $10 \%$ after the first ten isolated AVR procedures for each surgeon and a further $5 \%$ after the next ten implants, suggesting a short learning curve with the new technique. However, individual data varied and was likely biased by proctoring and teaching engagements by all of the surgeons, thus overestimating the required operating times.

For comparison, the mean ECC and cross-clamp times for the PF stentless valve that requires two suture lines were $136 \pm 65$ minutes (105 \pm 51 minutes) for isolated procedures and $147 \pm 28$ (115 \pm 24 minutes) for combined procedures, respectively. Therefore, for isolated and combined procedures, respectively, operating times for the FS are $20 \%$ and $36.5 \%$ shorter as a result of the ability to avoid one suture line.

\section{Operative mortality and early complications}

The logistic EuroScore for isolated and combined procedures were $8.2 \pm 6.8$ and $12.7 \pm 11.2(12.8 \pm 13.3)$, respectively. The overall 30 -day mortality in our cohort was $3.8 \%$ (1.8\% for isolated AVR and $6.1 \%$ for combined procedures) (Table 2). This
Table I Patient characteristics and operative data

\begin{tabular}{|c|c|c|c|}
\hline & Total & $\begin{array}{l}\text { AVR } \\
\text { isolated }\end{array}$ & $\begin{array}{l}\text { AVR } \\
\text { combined }\end{array}$ \\
\hline $\mathrm{N}$ & 423 & 226 & 197 \\
\hline Age (years) & $\begin{array}{l}74.0 \pm 7.8 \\
(40.9-90.5)\end{array}$ & $\begin{array}{l}73.4 \pm 8.3 \\
(41.0-90.5)\end{array}$ & $\begin{array}{l}74.6 \pm 7.2 \\
(40.9-90.3)\end{array}$ \\
\hline \multicolumn{4}{|l|}{ Sex } \\
\hline Male & 216 (5I.1\%) & 105 (46.5\%) & III (56.4\%) \\
\hline Female & 207 (48.9\%) & 121 (53.5\%) & $86(43.6 \%)$ \\
\hline BMI $\left(\mathrm{kg} / \mathrm{m}^{2}\right)$ & $\begin{array}{l}27.6 \pm 4.6 \\
(16.9-46.3)\end{array}$ & $\begin{array}{l}28.0 \pm 4.8 \\
(19.2-46.3)\end{array}$ & $\begin{array}{l}27.1 \pm 4.2 \\
(1.38-2.33)\end{array}$ \\
\hline BSA (Dubois) m² & $\begin{array}{l}1.86 \pm 0.21 \\
(1.27-2.56)\end{array}$ & $\begin{array}{l}1.87 \pm 0.21 \\
(1.27-2.56)\end{array}$ & $\begin{array}{l}1.84 \pm 0.20 \\
(19.2-46.2)\end{array}$ \\
\hline LVEF\% & $56 \pm 11$ & $57 \pm 10$ & $55 \pm 13$ \\
\hline Log STS-EuroScore & $\begin{array}{l}10.24 \pm 10.49 \\
(1.40-83.97)\end{array}$ & $\begin{array}{l}8.19 \pm 6.83 \\
(1.40-53.21)\end{array}$ & $\begin{array}{l}|2.67 \pm| 1.24 \\
(1.96-83.97)\end{array}$ \\
\hline \multicolumn{4}{|l|}{ Morbidities } \\
\hline Diabetes mellitus & $128(30.3)$ & $64(28.3)$ & $64(32.5)$ \\
\hline Arterial hypertension & $338(79.9)$ & $176(77.8)$ & $162(82.2)$ \\
\hline Renal impairment & $59(13.9)$ & $31(13.7)$ & $28(14.2)$ \\
\hline $\begin{array}{l}\text { Peripheral artery } \\
\text { disease }\end{array}$ & $43(10.2)$ & $23(10.2)$ & $20(10.1)$ \\
\hline Carotid stenosis & $4 \mid(9.7)$ & $17(7.5)$ & $24(12.2)$ \\
\hline COPD & $72(17.0)$ & $37(16.3)$ & $35(17.7)$ \\
\hline $\begin{array}{l}\text { History of cerebral } \\
\text { events }\end{array}$ & $31(7.3)$ & $17(7.5)$ & $14(7.1)$ \\
\hline \multicolumn{4}{|l|}{ Concomitant procedures ${ }^{\mathrm{a}}$} \\
\hline CABG & & - & $34(17.3)$ \\
\hline Grafts, n & & - & $1.9 \pm 1.0$ \\
\hline$C A B G+M V R$ & & - & $7(3.5)$ \\
\hline$C A B G+T V R$ & & - & $2(1.0)$ \\
\hline MVR (DVR) & & - & $18(9.3)$ \\
\hline MVR (DVR) + TVR & & - & $6(3.9)$ \\
\hline TVR & & - & $4(2.0)$ \\
\hline Ascendens tube graft & & - & $6(3.0)$ \\
\hline Ablation & & - & $16(8.1)$ \\
\hline PFO-closure & & - & II (5.6) \\
\hline Other & & - & $5(2.5)$ \\
\hline \multicolumn{4}{|l|}{ Labeled valve size } \\
\hline \#19 & $10(2.4)$ & $6(2.6)$ & $4(2.0)$ \\
\hline$\# 21$ & $109(25.8)$ & $62(27.4)$ & $47(23.8)$ \\
\hline \#23 & $133(3 \mid .4)$ & $69(30.5)$ & $64(32.5)$ \\
\hline$\# 25$ & $124(29.3)$ & $66(29.2)$ & $58(29.5)$ \\
\hline$\# 27$ & 47 (II.I) & $23(10.2)$ & $24(12.2)$ \\
\hline
\end{tabular}

Notes: ${ }^{a}$ One or more combined procedures. Unspecified data are $\mathrm{n}(\%)$ and mean \pm SD.

Abbreviations: AVR, aortic valve replacement; BMI, body mass index; BSA, body surface area; $C A B G$, coronary artery bypass grafting; COPD, chronic obstructive pulmonary disease; DVR, double valve replacement; LVEF, left ventricular ejection fraction; MVR, mitral valve repair/replacement; PFO, patent foramen ovale; SD, standard deviation; STS, Society of Thoracic Surgeons;TVR, tricuspid valve repair (annuloplasty).

data is comparable with $2.3 \%-4.9 \%$ mortality obtained with variable percentages of combined procedures $(16 \%-60 \%)$ reported elsewhere (Table 3). ${ }^{32-36}$ Causes of early death were low cardiac output/myocardial infarction, multiorgan failure, cerebral embolism, and septic endocarditis. None of the deaths was valve-related. Nonsurviving patients were significantly older $(78.3 \pm 5.0$ years vs $73.9 \pm 7.3$ years $)(P<0.05)$ and had a higher logistic EuroScore (17.4 \pm 22.1 vs 9.3 \pm 7.4$)$ ( $P=0.252)$ as compared with the surviving patients. 
Table 2 Outcome and complication in 423 consecutive patients receiving Freedom SOLO

\begin{tabular}{|c|c|c|c|}
\hline & Total & $\begin{array}{l}\text { AVR } \\
\text { isolated }\end{array}$ & $\begin{array}{l}\text { AVR } \\
\text { combined }\end{array}$ \\
\hline $\mathrm{n}$ & 423 & 226 & 197 \\
\hline ECC time, all (min) & $104 \pm 40$ & $89 \pm 29$ & $123 \pm 43$ \\
\hline Cross-clamp time, all (min) & $75 \pm 28$ & $64 \pm 21$ & $87 \pm 29$ \\
\hline RBC, units & $2.9 \pm 1.8^{\mathrm{a}}$ & $2.5 \pm 1.5^{c}$ & $3.3 \pm 2.1^{\mathrm{d}}$ \\
\hline Platelets, units & $1.8 \pm 1.1^{b}$ & $1.7 \pm 1.0^{\mathrm{e}}$ & $1.9 \pm 1.1^{f}$ \\
\hline 30-day mortality & $16(3.8)$ & $4(1.8)$ & $12(6.1)$ \\
\hline \multicolumn{4}{|l|}{ Cause of death } \\
\hline LCO & 9 & 2 & 7 \\
\hline Sepsis & 3 & I & 2 \\
\hline MOF & 2 & - & 2 \\
\hline Bleeding & 1 & 1 & - \\
\hline Neurology & 1 & - & I \\
\hline \multicolumn{4}{|l|}{ 30-day complications } \\
\hline Rethoracotomy for bleeding & II (2.6) & $4(1.7)$ & $7(5.5)$ \\
\hline Reversible cerebral event ${ }^{g}$ & $13(3.1)$ & $4(1.7)$ & $9(4.5)$ \\
\hline AKF, hemofiltration & $14(3.3)$ & $4(1.8)$ & $10(5.1)$ \\
\hline Wound infection & II (2.6) & $2(0.9)$ & $9(4.5)$ \\
\hline Permanent pacemaker & $8(1.9)$ & $3(1.3)$ & $5(2.5)$ \\
\hline Previously SR & $5(1.2)$ & $2(0.9)$ & $3(1.5)$ \\
\hline Previously AFib, heart block & $3(0.7)$ & $\mathrm{I}(0.4)$ & $2(0.7)$ \\
\hline \multicolumn{4}{|l|}{ 5-year complications } \\
\hline Endocarditis & $\mathrm{I}(0.2)$ & $\mathrm{I}(0.4)$ & - \\
\hline Prosthesis explantation & $4(0.9)$ & $\mathrm{I}(0.4)$ & $3(1.5)$ \\
\hline Severe regurgitation & $3(0.7)$ & - & $3(1.5)$ \\
\hline Severe stenosis & $\mathrm{I}(0.2)$ & $\mathrm{I}(0.4)$ & - \\
\hline SVD & - & - & - \\
\hline Thromboembolism & - & - & - \\
\hline PPM, moderate ${ }^{h}$ & $17(4.0)$ & $14(4.9)$ & $3(1.5)$ \\
\hline PPM, severe & - & - & - \\
\hline
\end{tabular}

Notes: ${ }^{5} 55.2 \%$ of patients received RBC units; ${ }^{\mathrm{b}} 12.7 \%$ of patients received platelet units; ' $52.8 \%$; ${ }^{\mathrm{d}} 57.9 \%$; ${ }^{\mathrm{e}} \mathrm{9} .7 \%$; ${ }^{\mathrm{f}} \mathrm{6} 6.5 \%$; ${ }^{86}$ patients with previous stroke; ${ }^{\mathrm{h}}$ patients' BMI: $34.7 \pm 3.8(28.3-40.6)$. Unspecified data are $n(\%)$ and mean $\pm S D$.

Abbreviations: AFib, atrial fibrillation; AKF, acute kidney failure; AVR, aortic valve replacement; BMI, body mass index; ECC, extracorporeal circulation; LCO, low cardiac output; MOF, multiorgan failure; PPM, prosthesis-patient mismatch; RBC, red blood cells; SD, standard deviation; SR, sinus rhythm; SVD, structural valve deterioration.

All patients left the operating room with no or trivial regurgitation. There were no other intraoperative events or technical complications with FS valve prosthesis implantations. The low rates of postoperative cerebral events (3.1\%), impaired renal function requiring temporary hemofiltration (3.3\%), or wound healing complications (2.6\%) were not different to AVR with stented prostheses (Table 2). All patients were discharged without further complications. The hospital lengths of stay for isolated and combined AVR were $9.6 \pm 1.9$ days and $11.0 \pm 2.8$ days, respectively.

\section{Requirement for permanent pacemaker}

Postoperative complete atrioventricular (AV) block and severe symptomatic bradycardia, as typical post-AVR complications, are rare in patients receiving the FS. Low rates, of $0 \%-3.0 \%$, of permanent pacemaker (PM) implantation have been reported for patients receiving the FS. $32,33,37,38$ This data is in line with the requirement for permanent PM implantation after isolated AVR with stented prostheses in $7.0 \%$ of patients, in a recent meta-analysis including 2,557 patients for best evidence analyses. ${ }^{39}$ The low rate of permanent PM (Table 2) in patients receiving the FS could be explained by the implantation technique, which strictly follows supra-annular positioning and therefore avoids trauma to the AV node or His bundle in the region of the membranous septum and right trigonum, beneath the $\mathrm{NC}$ to right coronary cusp commissure. Rare cases of damage to the conduction system could be explained by aggressive (excessive) decalcification in the area of the septum membranaceum just prior to prosthesis implantation.

\section{Hemodynamic performance: gradients at rest and under stress}

Clinical studies have shown that stentless valves in the subcoronary position provide residual transvalvular gradients similar to native valves and unmatched by traditional stented prostheses at early to midterm follow up. ${ }^{40}$ The hemodynamic data in our cohort are shown in Figure 3 and in Table 4 for individual valve sizes. Postoperative gradient reduction remained stable within valve size groups, with a slight trend toward lower mean gradients with increasing valve size. These low gradients may be of particular benefit for patients with preoperatively (impaired) poor LV function.

Most studies reported transvalvular gradients at rest, although gradients during stress (exercise) testing would better reflect prosthesis-related limitations. With increasing cardiac output, the transvalvular flow also increases and the rise in transprosthetic gradient is an important index for adequate valvular function. In general, at midterm follow up, gradients at rest and during exercise, as well as the rise, were found to be lower in patients with stentless prostheses compared with stented valves, indicating that the stentless valve may perform better under physiological stress. ${ }^{41,42}$

In patients after AVR with FS, resting and stress gradients have been investigated using the bicycle exercise test at 9.6 months postsurgery. ${ }^{36}$ During stress echocardiography, mean aortic gradients increased only from $4.4 \pm 1.7 \mathrm{mmHg}$ at rest to $7.0 \pm 2.7 \mathrm{mmHg}$ at peak stress, and the EOA increased from $1.74 \pm 0.33 \mathrm{~cm}^{2}$ to $1.80 \pm 0.36 \mathrm{~cm}^{2}$. Mean gradients at peak stress correlated better with resting indexed EOA than with the labeled prosthesis size. ${ }^{36}$ These data are in line with the ideal adaption of the FS prosthesis to the patient's anatomy, 
Table 3 Thirty-day mortality and long-term complications

\begin{tabular}{|c|c|c|c|c|c|c|}
\hline & $\mathbf{N}$ & $\begin{array}{l}\text { Mean follow-up } \\
\text { (years) }\end{array}$ & $\begin{array}{l}\text { 30-day } \\
\text { mortality }\end{array}$ & $\begin{array}{l}\text { At } \\
4 \text { years }\end{array}$ & $\begin{array}{l}\text { At } \\
8 \text { years }\end{array}$ & Reference \\
\hline \multirow[t]{6}{*}{ 30-day mortality } & 423 & $5.5 \pm 2.3$ & 3.8 & & & This study \\
\hline & 100 & $1.0 \pm 0.4$ & 3.0 & & & Oses et $\mathrm{a}^{32}$ \\
\hline & 77 & $3.1 \pm 0.1$ & 4.6 & & & Iliopoulos ${ }^{33}$ \\
\hline & 256 & $1.1 \pm 0.8$ & 2.3 & & & Beholz et $\mathrm{al}^{34}$ \\
\hline & 143 & $1.8 \pm 1.4$ & 4.9 & & & Horst et $\mathrm{al}^{35, \mathrm{a}}$ \\
\hline & 277 & $2.6 \pm 1.7$ & 4.3 & & & Thalmann et al ${ }^{37}$ \\
\hline \multirow[t]{3}{*}{ Freedom from endocarditis } & 149 & $5.5 \pm 2.3$ & & 0.98 & 0.96 & This study \\
\hline & 256 & $1.1 \pm 0.8$ & & 97.4 & & Beholz et $\mathrm{al}^{34}$ \\
\hline & 143 & $1.8 \pm 1.4$ & & 99.3 & & Horst et $\mathrm{al}^{35, \mathrm{a}}$ \\
\hline \multirow[t]{3}{*}{ Freedom from SVD } & 149 & $5.5 \pm 2.3$ & & 0.97 & 0.70 & This study \\
\hline & 256 & $1.1 \pm 0.8$ & & 1.00 & & Beholz et al ${ }^{34}$ \\
\hline & 143 & $1.8 \pm 1.4$ & & 100 & & Horst et a $\left.\right|^{35, a}$ \\
\hline \multirow[t]{3}{*}{ Freedom from explantation } & 149 & $5.5 \pm 2.3$ & & 0.96 & 0.81 & This study \\
\hline & 256 & $1.1 \pm 0.8$ & & 97.8 & & Beholz et al ${ }^{34}$ \\
\hline & 143 & $1.8 \pm 1.4$ & & 98.6 & & Horst et $\mathrm{a}^{35, \mathrm{a}}$ \\
\hline Freedom from explantation for SVD & 149 & $5.5 \pm 2.3$ & & 1.00 & 0.84 & This study \\
\hline \multirow[t]{3}{*}{ Freedom from thromboembolism } & 149 & $5.5 \pm 2.3$ & & 0.99 & 0.99 & This study \\
\hline & 256 & $1.1 \pm 0.8$ & & 98.8 & & Beholz et al ${ }^{34}$ \\
\hline & 143 & $1.8 \pm 1.4$ & & 1.00 & & Horst et a $\mathrm{a}^{35, \mathrm{a}}$ \\
\hline
\end{tabular}

Note: ${ }^{a}$ Data was observed at 4.7 years.

Abbreviation: SVD, structural valve deterioration.

following the natural motion of the annulus. Therefore, stentless valves could be preferable for more active patients, particularly those with a small aortic root.

\section{LV mass regression}

The LV mass regression (LVMR) is related to the EOA and the following decline in transaortic pressure difference. ${ }^{43}$ Postoperative regression of LVH, eg, decreases of LV end-diastolic diameter, LV end-systolic diameter, and interventricular septum thickness, following AVR with FS have been reported after 1 year. ${ }^{33,37}$ Compared with stented bioprostheses or mechanical valves, a more rapid and more complete resolution of $\mathrm{LVH}$ in relation to remodeling and improved function have been reported. ${ }^{44,45}$ In general, differences in LVMR between stented and stentless valves persisted until 1 year postsurgery, but not longer. ${ }^{43-47}$ Therefore, these results indicate that LVMR may occur faster in stentless valves during the first year postsurgery. ${ }^{47}$

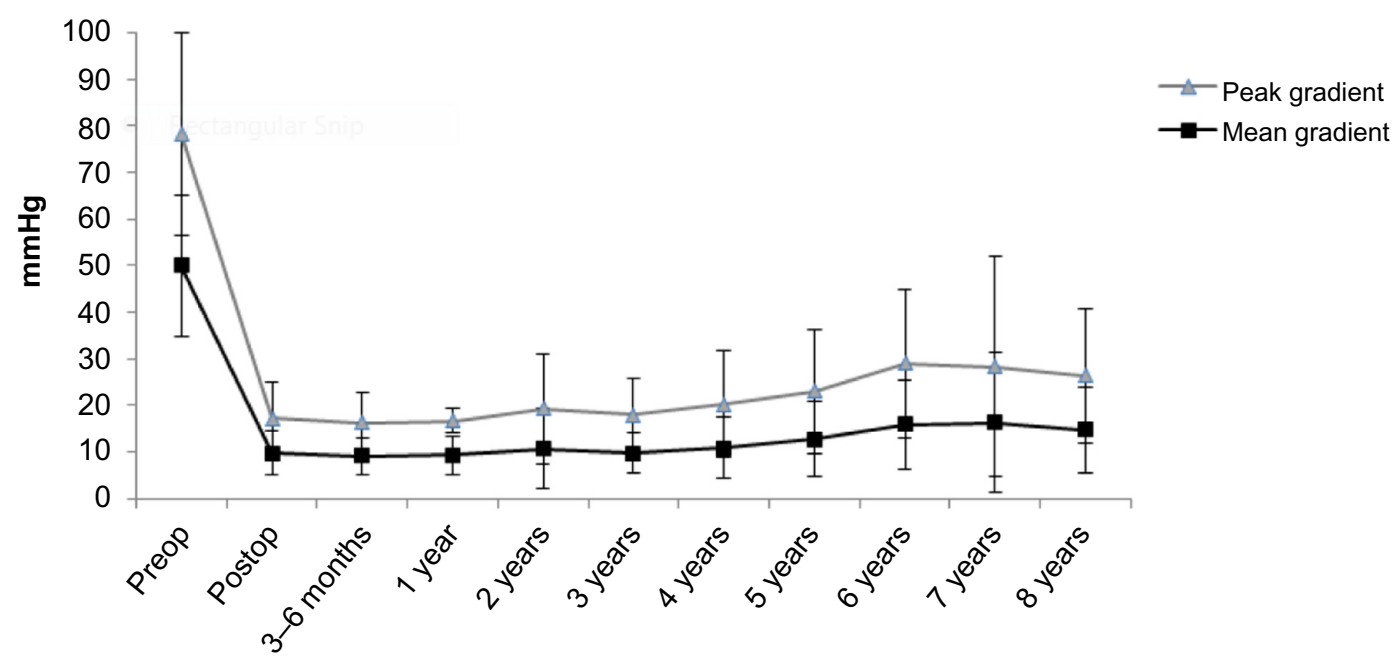

Figure 3 Gradients (peak and mean) after implantation of the Freedom SOLO valve. Abbreviations: Preop, preoperative; Postop, postoperative. 
Table 4 Gradients according to prosthesis size after AVR with Freedom SOLO

\begin{tabular}{|c|c|c|c|c|c|}
\hline & \multirow[t]{2}{*}{$\mathbf{N}$} & \multicolumn{4}{|l|}{ Gradients } \\
\hline & & Preoperative & 30 days & 6 months & I year \\
\hline${ }^{\# 19}$ & 10 & & & & \\
\hline Peak & & $73.2 \pm 30.3$ & $19.5 \pm 7.0$ & $17.4 \pm 7.0$ & $16.9 \pm 8.1$ \\
\hline Mean & & $50.1 \pm 21.0$ & $10.5 \pm 4.8$ & $11.0 \pm 4.9$ & $10.6 \pm 4.1$ \\
\hline${ }^{*} 21$ & 109 & & & & \\
\hline Peak & & $83.8 \pm 20.6$ & $18.3 \pm 6.4$ & $18.8 \pm 6.6$ & $18.0 \pm 8.7$ \\
\hline Mean & & $55.0 \pm 14.6$ & $9.9 \pm 3.8$ & $10.4 \pm 5.1$ & $9.9 \pm 3.9$ \\
\hline${ }^{\prime 2} 23$ & 133 & & & & \\
\hline Peak & & $75.7 \pm 22.4$ & $17.5 \pm 6.4$ & $16.1 \pm 6.2$ & $16.0 \pm 7.8$ \\
\hline Mean & & $47.6 \pm 15.0$ & $9.9 \pm 3.5$ & $9.2 \pm 3.5$ & $9.6 \pm 4.6$ \\
\hline${ }^{\# 25}$ & 124 & & & & \\
\hline Peak & & $77.8 \pm 19.8$ & $14.6 \pm 5.5$ & $13.6 \pm 4.7$ & $13.8 \pm 4.3$ \\
\hline Mean & & $48.6 \pm 14.4$ & $8.3 \pm 3.2$ & $7.9 \pm 2.8$ & $7.9 \pm 2.2$ \\
\hline${ }^{\prime 27}$ & 47 & & & & \\
\hline Peak & & $66.3 \pm 26.9$ & $14.5 \pm 5.9$ & $14.8 \pm 6.4$ & $13.8 \pm 7.4$ \\
\hline Mean & & $43.6 \pm 16.0$ & $8.0 \pm 3.1$ & $8.5 \pm 3.4$ & $7.4 \pm 2.8$ \\
\hline Total & 423 & & & & \\
\hline Peak & & $77.4 \pm 22.1$ & $15.9 \pm 5.8$ & $15.7 \pm 6.7$ & $16.2 \pm 7.7$ \\
\hline Mean & & $49.1 \pm 15.0$ & $9.1 \pm 3.5$ & $8.8 \pm 3.2$ & $9.3 \pm 4.3$ \\
\hline
\end{tabular}

Note: Data are presented as mean \pm standard deviation.

Abbreviation: AVR, aortic valve replacement.

\section{EOA and prosthesis-patient mismatch}

Prosthesis-patient mismatch (PPM) has been associated with higher gradients (at rest and particularly under stress conditions), blunted LVMR, ${ }^{48}$ and increased all-cause and cardiacrelated mortality over long-term follow up, particularly in younger patients, females, and patients with preoperative LV dysfunction. ${ }^{49}$ As generally accepted, PPM is best characterized by the ratio of prosthetic EOA to the patient's body surface area (BSA). PPM is defined as an indexed EOA between 0.85-0.65 $\mathrm{cm}^{2} / \mathrm{m}^{2}$ (moderate) and $<0.65 \mathrm{~cm}^{2} / \mathrm{m}^{2}$ (severe), which is the common cutoff value for all kinds of prosthetic valves. ${ }^{48}$ Depending on prosthesis size, the EOA increases two- to threefold after FS implantation and was reported (mean \pm standard deviation [SD]) for the valve sizes 19, 21, 23, 25, and 27, as $1.49 \pm 0.32 \mathrm{~cm}^{2}, 1.67 \pm 0.40 \mathrm{~cm}^{2}, 1.92 \pm 0.38 \mathrm{~cm}^{2}, 2.01 \pm 0.42 \mathrm{~cm}^{2}$, and $2.13 \pm 0.36 \mathrm{~cm}^{2}$, respectively. ${ }^{37}$ Calculations for the indexed EOA (EOA/BSA) indicated complete absence of severe PPM with the FS valve prosthesis, and only moderate PPM in 17 patients $(4.0 \%)$ with a BSA of $2.09 \pm 0.2 \mathrm{~m}^{2}$ (body mass index $[\mathrm{BMI}] 34.5 \pm 3.9 \mathrm{~kg} / \mathrm{m}^{2}$ ). Due to the favorable EOA with absence of obstructive stents, this valve appears particularly attractive for patients at risk for PPM, ie, those with a small aortic root.

However, new-generation stented valves, eg, the Carpentier-Edwards Perimount Magna Ease (Edwards Lifesciences, Irvine, CA, USA), Mitroflow (Sorin Biomedica) and the Trifecta ${ }^{\mathrm{TM}}$ (St Jude Medical, St Paul, MN, USA), were shown to have noninferior EOA compared with the FS, with favorable hemodynamic performance and with low rates of PPM due to improved design. ${ }^{50}$ As such, the EOA for the various valve sizes $19-27$ ranged from $1.53-3.20 \mathrm{~cm}^{2}$, with mean gradients of 4.7-11.4 $\mathrm{mmHg}$, for the Trifecta bioprosthesis at 1 year. ${ }^{50,51}$ The corresponding EOA and gradients for the Perimount Magna Ease valves ranged from $2.09-2.80 \mathrm{~cm}^{2}$ and $11.3-14.1 \mathrm{mmHg},{ }^{50}$ with near absence $(\leq 1 \%)$ of PPM. ${ }^{52,53}$

\section{Coronary flow and coronary flow reserve}

Coronary flow (CF) (perfusion) and coronary flow reserve (CFR) patterns are impaired in patients with aortic stenosis. In fact, valve-related chronic coronary hypoperfusion and reduced CFR may cause angina pectoris, arrhythmia, deteriorating LV function, ${ }^{54}$ and sudden cardiac death, and were shown to be independent predictors of cardiovascular prognosis. $^{55}$

Given that $\mathrm{CF}$ is determined by the diastolic flow pattern within the sinus of Valsalva, restoration of postoperative CFR depends on the turbulence downstream of the valve, which in turn, is fundamentally dependent on prosthesis design and orientation. ${ }^{54,55}$ Optimal valve orientation with respect to hemodynamics results in CF rates closest to normal physiology. The correlation between systolic performance and CF is explained by low levels of turbulence downstream during systole, which also affects diastolic backflow. Thus, the optimally oriented valve allows normal diastolic regurgitation into the sinuses of Valsalva and provides the highest $\mathrm{CF}$ rates. ${ }^{54}$ As demonstrated with magnetic resonance imaging (MRI), postoperative increases in CF and CFR were significantly higher in patients receiving stentless valves (Medtronic Freestyle $^{\circledR}$ ) than stented prostheses (Medtronic Mosaic ${ }^{\circledR}$ ). ${ }^{56}$ Furthermore, normalization of CFR after AVR in patients with aortic stenosis (AS) was observed only for stentless valves and not with stented bioprostheses (Medtronic Mosaic) or with mechanical valves (Medtronic Hall; Medtronic Advantage $\left.{ }^{\circledR}\right) .{ }^{57}$ Importantly, no correlation between valve size and $\mathrm{CF}$ rates was observed. ${ }^{54}$ In conclusion, compared with stented bioprostheses or mechanical valves, use of stentless valves provides superior hemodynamic performance, including increased $\mathrm{CF}$ and restoration of a normal CFR.

\section{Transient postoperative thrombocytopenia}

In agreement with previous reports, ${ }^{27,32-34,58-60}$ we observed a more severe postoperative platelet decrease following implantation of the FS when compared with stented bioprostheses. 
The minimal platelet count was observed on the second postoperative day (mean $-62 \%$ ). Importantly, we and others have not observed associated excess bleeding complications or increased reexploration rates despite this transient thrombocytopenia. In comparison, platelet numbers recovered to baseline values $(100 \%)$ on postoperative day 6 and 9 , for the Mitroflow and FS, respectively (Figure 4). The initial discovery of this FS-associated phenomenon came about with the investigation into the cause of unexpected increases in requested heparin-induced thrombocytopenia (HIT) tests following AVR in patients receiving this prosthesis. ${ }^{27,59}$ However, no evidence suggests any link to HIT. ${ }^{61}$ Platelet activation and aggregation result in diffuse platelet consumption and decreased platelet count, but to date, no FS-associated thromboembolic complications have been reported. Furthermore, no impairment in platelet-fibrinogen interactions for thrombus formation and no change in postoperative platelet function have been observed. ${ }^{62}$ Causal hemodynamic stress appears highly unlikely given the large EOA and low gradients of a correctly sized FS, ${ }^{37}$ with performances similar to native aortic valves under rest and stress conditions. ${ }^{63}$

At this point, the precise mechanism of FS-dependent thrombocytopenia remains to be identified. As mentioned, the FS bioprosthesis undergoes antimineralization treatment with $\mathrm{HCA}$, a reactive intracellular oxidation product of the sulfurcontaining amino acid homocysteine, which is usually not measurable in peripheral blood. An alternative hypothesis to explain FS-associated postoperative thrombocytopenia could be the platelet lysis induced through HCA-dependent hyperactivation of membrane N-methyl-D-aspartic acid (NMDA)type glutamate receptors on activated platelets. This receptor activation can be followed by increases in intracellular levels of ionized calcium, cyclic adenosine monophosphate (cAMP) levels, and reactive oxygen species (ROS), which trigger expression of proapoptotic genes, progressive cellular degeneration, and cell lysis within hours of even short-term HCA exposures. ${ }^{64,65}$ This mechanism may be limited to the subgroup of platelets that are particularly susceptible to damage and stimulation after ECC. Furthermore, the short, nonpersistent damaging effect would also be limited to the short time when the FS surface is fully exposed following implantation, explaining the transient decrease of platelet numbers with recovery.

\section{Long-term outcome and reoperation}

Numerous reports have documented superior early and midterm hemodynamic results following stentless valve prostheses implantation, including the FS. ${ }^{47,66}$ However, stentless valves must demonstrate at least noninferiority to stented bioprostheses in long-term outcomes studies to obtain full acceptance. The FS was introduced in 2004, and we are thus now approaching a critical observation period, which will enable evaluation of the long-term durability of the FS prosthesis and the validity of the concept of current third-generation stentless valves. Not much data on the FS with longer observation periods has been published (Table 3). Rates for freedom from endocarditis, SVD, explantation, and explantation for SVD after 8 years in a cohort of 149 patients were 0.96 (0.90-0.99), 0.70 (0.57-0.80), 0.81 (0.67-0.89), and 0.84 (0.70-0.92), respectively (Figure 5). In all cases of nonsclerotic SVD, acute vertical tears of the noncorornary cusp were located in close proximity to the commissure, and in our series, they occurred, on average, 1.5 years (6.0 vs 7.5 years) earlier than explantation for degenerative stenosis.

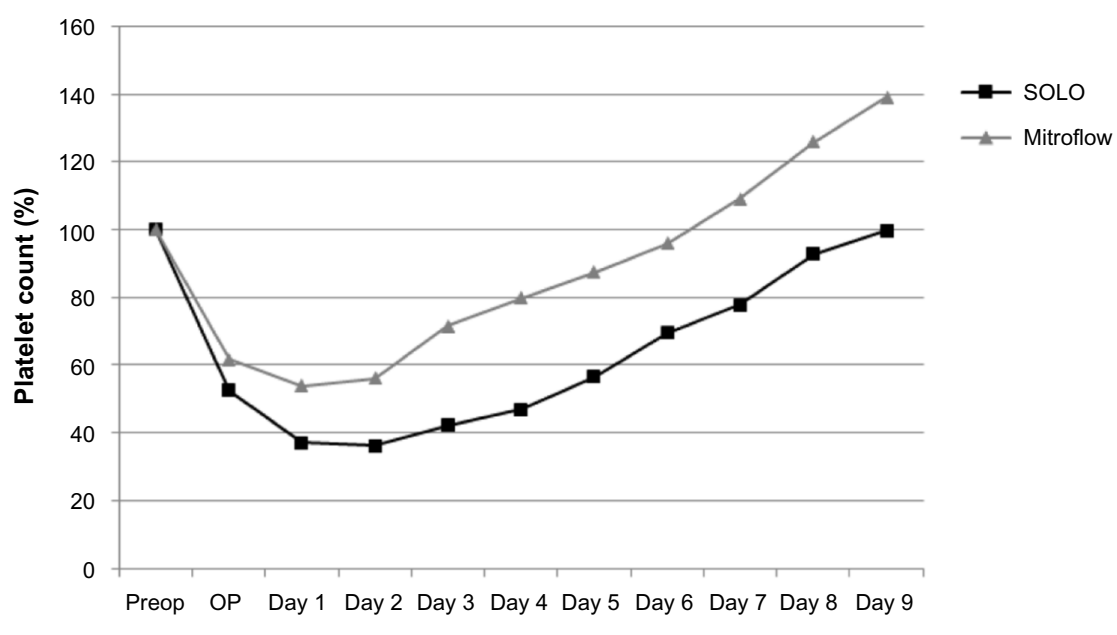

Figure 4 Platelet count after implantation of Freedom SOLO stentless and Mitroflow stented bioprostheses. Abbreviations: OP, day of operation; Preop, preoperation. 


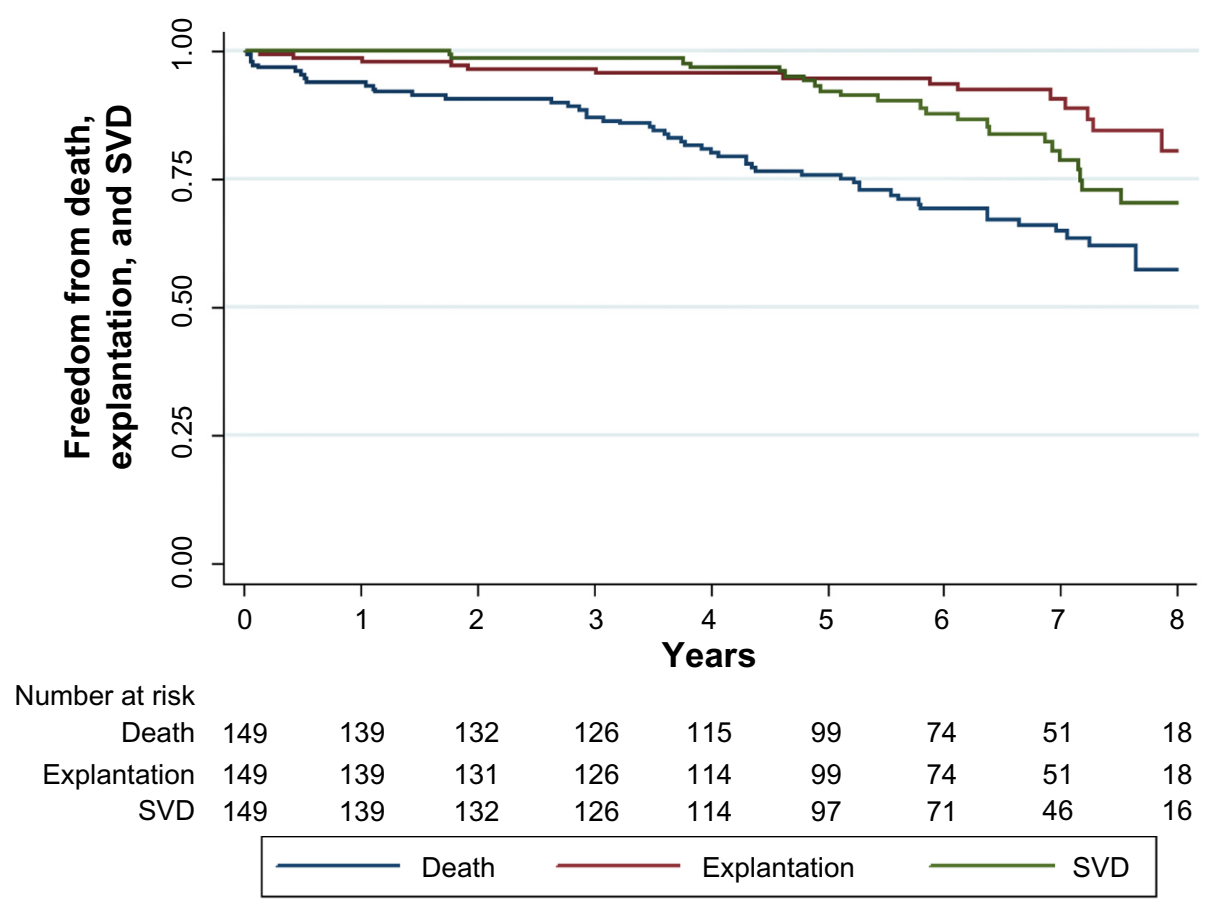

Figure 5 Kaplan-Meier estimates for freedom from death, SVD, and explantation. Abbreviation: SVD, structural valve deterioration.

Calcification was always strikingly severe and included the entire aortic root.

FS prostheses with tears and cusp ruptures were relatively easy to replace. In contrast, the majority of cases with severe calcification turned out to be very difficult to decalcify. FS valves were replaced with prostheses at least one size smaller than the original FS size. In some extremely demanding cases, a complete root replacement may be necessary. Our experience confirms the findings of a previous report that reoperations after stentless AVR are challenging and more complex procedures than a simple "redo" of AVR and are associated with increased operative risks. ${ }^{67}$ Alternatively, successful treatment of stenotic FS with transcatheter aortic valve implantation (TAVI) has been reported and may become increasingly important. ${ }^{68}$

\section{Conclusion}

Stentless valves were developed to mimic as much as possible the anatomy and physiology of the native aortic valve and to simplify and standardize the method of implantation.

The third-generation FS valve is a very attractive alternative to stented bioprostheses. The design, and tissue and anticalcification treatment fulfill most, if not all, requirements of an ideal valve substitute. The FS pericardium stentless valve combines the single-suture, subcoronary implantation technique with the latest-generation bovine pericardial tissue and novel anticalcification treatment. The design allows a good imitation of the native healthy aortic valve through unrestricted adaption to the patient's anatomy, reproducing a normal valve/root complex. Further advantages of the FS include the absence of subclinical hemolysis, ${ }^{69}$ the absence of imaging artifacts (on computed tomography [CT]/MRI), and potential strut-related obstruction of coronary ostia.

Thus, in theory, stentless valve function and durability have been expected to be superior to those of stented valves. However, despite the fact that the majority of patients undergoing AVR with bioprostheses have a remaining lifetime of less than 10 to 12 years, major concerns for stentless prostheses relate to issues regarding long-term durability. Whereas many investigators report consistently on short-term outcome with excellent early hemodynamic performance, long-term durability of these valves is rarely reported and remains largely uncharacterized. Furthermore, there are concerns of early structural and nonstructural deterioration. In fact, no stentless valve has proven superiority for longterm durability.

A number of stentless models have been developed and introduced, but all have been fundamentally different with respect to design, and tissue and anticalcification treatment, rendering comparisons difficult. One point of criticism has been the variety of implantation techniques (subcoronary, "miniroot", and full-root replacement), all of which are 
considered more complex procedures requiring two or more suture lines and consequently, accounting for a longer operating time as compared with stented valves.

Freedom from thromboembolism and endocarditis following bioprosthetic valve replacement is usually very good, with values typically greater than $90 \%$ at 7 to 10 years. ${ }^{70}$ However, after approximately 10 years, freedom from SVD and reoperation dropped dramatically in earlier porcine models, eg, the O'Brien (CryoLife, Atlanta, GA, USA) ${ }^{71}$ Shelhigh (Shelhigh, Inc., Millburn, NJ, USA), ${ }^{72}$ and Biocor ${ }^{\mathrm{TM}}$ (St Jude Medical). ${ }^{73}$ Furthermore, the freedom from SVD and explantation for SVD in our cohort was $0.84(0.70-0.92)$ and $0.76(0.50-0.89)$, respectively, after 8 and 9 years, which is comparable with similar data reported for the subcoronary Toronto stentless valve. These results imply then that the durability is lower than that of traditional stented prostheses. ${ }^{70}$

If, despite all the beneficial aspects mentioned above, durability is inferior to stented valves, must we question manufacturing details or the whole stentless concept? It is difficult to see where the design can undergo further improvement. Reoperation includes valve-dependent but also valve-independent failure. Therefore we have learned that outcomes also depend on optimal patient selection and observance of the limitations for the use of stentless valves, particularly with the FS.

Importantly, the stentless valve prosthesis concept ideally assumes that it can replace and imitate a native valve, thus adopting nearly identical functional durability. However, this theoretical idea ignores that the stentless valve may not seat adequately in the native aortic root. Optimal performance and long-term freedom from SVD depends on perfectly symmetric implantation, to provide low leaflet stress. In reality, this is only rarely obtained since the distribution of the three sinuses is never really symmetrical. As a fundamental difference, the function of stented valves is fully separated from the sinus function, whereas stentless valves are fully exposed to the interaction between aortic root dynamics and valve mechanics. Any malpositioning can thus lead to tissue fatigue over time. Given the large individual variability in root anatomy, particularly of the NC sinus, which is usually larger than the left coronary and right coronary sinuses (with corresponding larger volume, increased height, width, leaflet size, and thickness) ${ }^{74}$ symmetric implantation and tension-free positioning can hardly be guaranteed. Therefore, any asymmetry between the native anatomy and the stentless tissue valve may cause small distortions, with eccentric regurgitation, increased chronic mechanical stress, and premature valve deterioration. Whereas a compliant aortic root contributes substantially to smooth and symmetrical leaflet opening with minimal gradients, this effect is strikingly absent with stiff roots and may also contribute to premature SVD. ${ }^{75}$ At least, the annulus must be considered stiff and noncompliant in patients with sclerotic aortic stenosis, arguing for impaired root physiology with implication for prosthesis durability.

In this review, we have described the implantation technique for the FS, including pitfalls in detail, and have given an overview of our own clinical experience. Beyond doubt and in contrast to stented valves, despite the single suture line and reproducible outcomes through more standardized techniques, stentless valve implantation still requires more demanding techniques, more experienced surgeons, and surgeon-dependent skills, which include good judgment, proper patient selection, and respect for limitations. We are now approaching a period of observation, which will be critical in defining the concept of current third-generation stentless valves. Regardless of whether or not stentless valve durability surpasses third-generation stented bioprostheses, stentless valves will continue to play a role in the surgical repertoire.

\section{Acknowledgment}

We are grateful to Sarah Longnus and Brigitta Gahl for excellent technical assistance in preparing and reviewing the manuscript.

\section{Disclosure}

The authors report no conflict of interest in this work.

\section{References}

1. Hufnagel CA, Harvey WP, Rabil PJ, McDermott TF. Surgical correction of aortic insufficiency. Surgery. 1954;35(5):673-683.

2. Ross DN. Homograft replacement of the aortic valve. Lancet. 1962; 2(7254):487-488.

3. Barratt-Boyes BG. Homograft aortic valve replacement in aortic incompetence and stenosis. Thorax. 1964;19(2):131-150.

4. Harken DE, Soroff HS, Taylor WJ, Lefemine AA, Gupta SK, Lunzer S. Partial and complete prostheses in aortic insufficiency. $J$ Thorac Cardiovasc Surg. 1960;40:744-762.

5. Weldon CS, Ameli MM, Morovati SS, Shaker IJ. A prosthetic stented aortic homograft for mitral valve replacement. J Surg Res. 1966;6(12):548-552.

6. Duran CG, Gunning AJ. Heterologous aortic valve transplantation in the dog. Lancet. 1965;1(7403):114-115.

7. Binet JP, Carpentier A, Langlois J, Duran C, Colvez P. [Implantation of heterogenic valves in the treatment of aortic cardiopathies]. C R Acad Sci Hebd Seances Acad Sci D. 1965;261(25):5733-5734. French.

8. Binet JP, Duran CG, Carpentier A, Langlois J. Heterologous aortic valve transplantation. Lancet. 1965;286(7425):1275.

9. Carpentier A, Deloche A, Relland J, et al. Six-year follow-up of glutaraldehyde-preserved heterografts. With particular reference to the treatment of congenital valve malformations. J Thorac Cardiovasc Surg. 1974;68(5):771-782.

10. Reis RL, Hancock WD, Yarbrough JW, Glancy DL, Morrow AG. The flexible stent. A new concept in the fabrication of tissue heart valve prostheses. J Thorac Cardiovasc Surg. 1971;62(5):683-689. 
11. Bortolotti U, Milano A, Thiene G, et al. Early mechanical failures of the Hancock pericardial xenograft. J Thorac Cardiovasc Surg. 1987;94(2):200-207.

12. Harken DE. Heart valves: ten commandments and still counting. Ann Thorac Surg. 1989;48(Suppl 3):S18-S19.

13. Walkes JC, Reardon MJ. Current thinking in stentless valve surgery. Curr Opin Cardiol. 2003;18(2):117-123.

14. O'Brien MF. The Cryolife-O'Brien composite aortic stentless xenograft: surgical technique of implantation. Ann Thorac Surg. 1995; 60(Suppl 2):S410-S413.

15. Dagum P, Green GR, Nistal FJ, et al. Deformational dynamics of the aortic root: modes and physiologic determinants. Circulation. 1999;100(Suppl 19):II54-II62.

16. Levy D, Garrison RJ, Savage DD, Kannel WB, Castelli WP. Prognostic implications of echocardiographically determined left ventricular mass in the Framingham Heart Study. N Engl J Med. 1990;322(22): $1561-1566$

17. Lund O. Valve replacement for aortic stenosis: the curative potential of early operation. Scand J Thorac Cardiovasc Surg Suppl. 1993;40:S1-S137.

18. Stacchino C, Bona G, Rinaldi S, Vallana F. Design and performance characteristics of the Pericarbon Stentless valve. J Heart Valve Dis. 1995;4 Suppl 1:S102-S105.

19. Stacchino C, Bona G, Bonetti F, et al A. Grignani. Detoxification process for glutaraldehyde-treated bovine pericardium: biological, chemical and mechanical characterization. J Heart Valve Dis. 1998;7(2),190-194.

20. Repossini A, Kotelnikov I, Bouchikhi R, et al. Single-suture line placement of a pericardial stentless valve. J Thorac Cardiovasc Surg. 2005;130(5):1265-1269.

21. O'Brien MF. Implantation technique of the Cryolife-O'Brien stentless xenograft aortic valve: the simple, rapid, and correct way to implant and the errors to avoid. Semin Thorac Cardiovasc Surg. 1999;11(4 Suppl 1): S121-S125.

22. Scharfschwerdt M, Sievers HH, Hussein A, Kraatz EG, Misfeld M. Impact of progressive sinotubular junction dilatation on valve competence of the 3F Aortic and Sorin Solo stentless bioprosthetic heart valves. Eur J Cardiothorac Surg. 2010;37(3):631-634.

23. David TE, Feindel CM, Bos J, Ivanov J, Armstrong S. Aortic valve replacement with Toronto SPV bioprosthesis: optimal patient survival but suboptimal valve durability. J Thorac Cardiovasc Surg. 2008;135(1):19-24.

24. Glauber M, Solinas M, Karimov J. Technique for implant of the stentless aortic valve Freedom Solo. Multimed Man Cardiothorac Surg [serial on the Internet]. Jan 2007 [cited September 21, 2014]; 2007(1018):[about 10 p]. http://mmcts.oxfordjournals.org/content/2007/1018/mmcts.2007.002618. full.pdf+html. Accessed September 21, 2014.

25. Permanyer E, Ginel A, Muñoz-Guijosa C, Padró JM. The Sorin Freedom SOLO stentless aortic valve: easier implantation technique with potentially less risk of complications. Eur J Cardiothorac Surg. 2011;40(5):1263-1264.

26. Beholz S, Konertz WE. Avoiding early partial valve thrombosis of the Pericarbon Freedom stentless valve. J Heart Valve Dis. 2007; 16(1):91-92.

27. Hilker L, Wodny M, Ginesta M, Wollert HG, Eckel L. Differences in the recovery of platelet counts after biological aortic valve replacement. Interact Cardiovasc Thorac Surg. 2009;8(1):70-73.

28. Sinha P, Zurakowski D, Kumar TK, He D, Rossi C, Jonas RA. Effects of glutaraldehyde concentration, pretreatment time, and type of tissue (porcine versus bovine) on postimplantation calcification. J Thorac Cardiovasc Surg. 2012;143(1):224-227.

29. Valente M, Pettenazzo E, Thiene G, et al. Detoxified glutaraldehyde crosslinked pericardium: tissue preservation and mineralization mitigation in a subcutaneous rat model. J Heart Valve Dis. 1998;7(3):283-291.

30. Ozaki S, Herijgers P, Flameng W. Influence of blood contact on the calcification of glutaraldehyde-pretreated porcine aortic valves. Ann Thorac Cardiovasc Surg. 2003;9(4):245-252.
31. Perrotta S, Lentini S. In patients with severe active aortic valve endocarditis, is a stentless valve as good as the homograft? Interact Cardiovasc Thorac Surg. 2010;11(3):309-313.

32. Oses P, Guibaud JP, Elia N, et al. Freedom SOLO valve: early- and intermediate-term results of a single centre's first 100 cases. Eur $J$ Cardiothorac Surg. 2011;39(2):256-261.

33. Iliopoulos DC, Deveja AR, Androutsopoulou V, et al. Single-center experience using the Freedom SOLO aortic bioprosthesis. J Thorac Cardiovasc Surg. 2013;146(1):96-102.

34. Beholz S, Repossini A, Livi U, et al. The Freedom SOLO valve for aortic valve replacement: clinical and hemodynamic results from a prospective multicenter trial. J Heart Valve Dis. 2010;19(1):115-123.

35. Horst M, Easo J, Hölzl PP, et al. The Freedom SOLO valve: mid-term clinical results with a stentless pericardial valve for aortic valve replacement. J Heart Valve Dis. 2011;20(6):704-710.

36. Repossini A, Rambaldini M, Lucchetti V, et al. Early clinical and haemodynamic results after aortic valve replacement with the Freedom SOLO bioprosthesis (experience of Italian multicenter study). Eur $J$ Cardiothorac Surg. 2012;41(5):1104-1110.

37. Thalmann M, Kaiblinger J, Krausler R, et al. Clinical experience with the Freedom SOLO stentless aortic valve in 277 consecutive patients. Ann Thorac Surg. Epub August 20, 2014.

38. Aymard T, Eckstein F, Englberger L, Stalder M, Kadner A, Carrel T. The Sorin Freedom SOLO stentless aortic valve: technique of implantation and operative results in 109 patients. J Thorac Cardiovasc Surg. 2010;139(3):775-777.

39. Matthews IG, Fazal IA, Bates MG, Turley AJ. In patients undergoing aortic valve replacement, what factors predict the requirement for permanent pacemaker implantation? Interact Cardiovasc Thorac Surg. 2011;12(3):475-479.

40. Dellgren G, Feindel CM, Bos J, Ivanov J, David TE. Aortic valve replacement with the Toronto SPV: long-term clinical and hemodynamic results. Eur J Cardiothorac Surg. 2002;21(4):698-702.

41. Kunadian B, Vijayalakshmi K, Thornley AR, et al. Meta-analysis of valve hemodynamics and left ventricular mass regression for stentless versus stented aortic valves. Ann Thorac Surg. 2007;84(1):73-78.

42. Silberman S, Shaheen J, Fink D, et al. Comparison of exercise hemodynamics among nonstented aortic bioprostheses, mechanical valves, and normal native aortic valves. J Card Surg. 1998;13(5):412-416.

43. Del Rizzo DF, Abdoh A, Cartier P, Doty D, Westaby S. Factors affecting left ventricular mass regression after aortic valve replacement with stentless valves. Semin Thorac Cardiovasc Surg. 1999; 11(4 Suppl 1):114-120.

44. Maselli D, Pizio R, Bruno LP, Di Bella I, De Gasperis C. Left ventricular mass reduction after aortic valve replacement: homografts, stentless and stented valves. Ann Thorac Surg. 1999;67(4):966-971.

45. Walther T, Falk V, Langebartels G, et al. Regression of left ventricular hypertrophy after stentless versus conventional aortic valve replacement. Semin Thorac Cardiovasc Surg. 1999;11(4 Suppl 1):S18-S21.

46. Cohen G, Zagorski B, Christakis GT, et al. Are stentless valves hemodynamically superior to stented valves? Long-term follow-up of a randomized trial comparing Carpentier-Edwards pericardial valve with the Toronto Stentless Porcine Valve. J Thorac Cardiovasc Surg. 2010;139(4):848-859.

47. Funder JA. Current status on stentless aortic bioprosthesis: a clinical and experimental perspective. Eur J Cardiothorac Surg. 2012;41(4):790-799.

48. Pibarot P, Dumesnil JG. Prosthesis-patient mismatch: definition, clinical impact, and prevention. Heart. 2006;92(8):1022-1029.

49. Head SJ, Mokhles MM, Osnabrugge RL, et al. The impact of prosthesispatient mismatch on long-term survival after aortic valve replacement: a systematic review and meta-analysis of 34 observational studies comprising 27186 patients with 133141 patient-years. Eur Heart J. 2012;33(12):1518-1529.

50. Ugur M, Suri RM, Daly RC, et al. Comparison of early hemodynamic performance of 3 aortic valve bioprostheses. JThorac Cardiovasc Surg. Epub January 15, 2014. 
51. Bavaria JE, Desai ND, Cheung A, et al. The St Jude Medical Trifecta aortic pericardial valve: results from a global, multicenter, prospective clinical study. J Thorac Cardiovasc Surg. 2014;147(2):590-597.

52. Wyss TR, Bigler M, Stalder M, et al. Absence of prosthesis-patient mismatch with the new generation of Edwards stented aortic bioprosthesis. Interact Cardiovasc Thorac Surg. 2010;10(6):884-887; discussion 887-888.

53. Wendt D, Thielmann M, Plicht B, et al. The new St Jude Trifecta versus Carpentier-Edwards Perimount Magna and Magna Ease aortic bioprosthesis: is there a hemodynamic superiority? J Thorac Cardiovasc Surg. 2014;147(5):1553-1560.

54. Bakhtiary F, Schiemann M, Dzemali O, et al. Stentless bioprostheses improve postoperative coronary flow more than stented prostheses after valve replacement for aortic stenosis. J Thorac Cardiovasc Surg 2006;131(4):883-888.

55. Britten MB, Zeiher AM, Schächinger V. Microvascular dysfunction in angiographically normal or mildly diseased coronary arteries predicts adverse cardiovascular long-term outcome. Coron Artery Dis. 2004;15(5):259-264.

56. Hildick-Smith DJ, Shapiro LM. Coronary flow reserve improves after aortic valve replacement for aortic stenosis: an adenosine transthoracic echocardiography study. J Am Coll Cardiol. 2000;36(6):1889-1896.

57. Bakhtiary F, Schiemann M, Dzemali O, et al. Impact of patient-prosthesis mismatch and aortic valve design on coronary flow reserve after aortic valve replacement. J Am Coll Cardiol. 2007;49(7):790-796.

58. Pozzoli A, De Maat GE, Hillege HL, Boogaard JJ, Natour E, Mariani MA. Severe thrombocytopenia and its clinical impact after implant of the stentless Freedom Solo bioprosthesis. Ann Thorac Surg. 2013;96(5): 1581-1586.

59. Yerebakan C, Kaminski A, Westphal B, et al. Thrombocytopenia after aortic valve replacement with the Freedom Solo stentless bioprosthesis. Interact Cardiovasc Thorac Surg. 2008;7(4):616-620.

60. Ravenni G, Celiento M, Ferrari G, et al. Reduction in platelet count after aortic valve replacement: comparison of three bioprostheses. J Heart Valve Dis. 2012;21(5):655-661.

61. Selleng S, Malowsky B, Strobel U, et al. Early-onset and persisting thrombocytopenia in post-cardiac surgery patients is rarely due to heparin-induced thrombocytopenia, even when antibody tests are positive. J Thromb Haemost. 2010;8(1):30-36.

62. Tarzia V, Bottio T, Buratto E, Spiezia L, Simioni P, Gerosa G. Freedom solo stentless aortic valve: quantitative and qualitative assessment of thrombocytopenia. Ann Thorac Surg. 2011;92(5):1935.
63. Khoo JP, Davies JE, Ang KL, Galiñanes M, Chin DT. Differences in performance of five types of aortic valve prostheses: haemodynamic assessment by dobutamine stress echocardiography. Heart. 2013;99(1): 41-47.

64. Adalbert R, Engelhardt JI, Siklós L. DL-Homocysteic acid application disrupts calcium homeostasis and induces degeneration of spinal motor neurons in vivo. Acta Neuropathol. 2002;103(5):428-436.

65. Boldyrev AA. Molecular mechanisms of homocysteine toxicity. Biochemistry (Mosc). 2009;74(6):589-598.

66. Kobayashi J. Stentless aortic valve replacement: an update. Vasc Health Risk Manag. 2011;7:345-351.

67. Borger MA, Prasongsukarn K, Armstrong S, Feindel CM, David TE. Stentless aortic valve reoperations: a surgical challenge. Ann Thorac Surg. 2007;84(3):737-743; discussion 743-744.

68. Dvir D, Webb JG, Bleiziffer S, et al; Valve-in-Valve International Data Registry Investigators. Transcatheter aortic valve implantation in failed bioprosthetic surgical valves. JAMA. 2014;312(2):162-170.

69. Mecozzi G, Milano AD, De Carlo M, et al. Intravascular hemolysis in patients with new-generation prosthetic heart valves: a prospective study. J Thorac Cardiovasc Surg. 2002;123(3):550-556.

70. Desai ND, Merin O, Cohen GN, et al. Long-term results of aortic valve replacement with the St Jude Toronto stentless porcine valve. Ann Thorac Surg. 2004;78(6):2076-2083.

71. Pavoni D, Badano LP, Ius F, et al. Limited long-term durability of the Cryolife O'Brien stentless porcine xenograft valve. Circulation. 2007;116(Suppl 11):I307-I313.

72. Carrel TP, Schoenhoff FS, Schmidli J, Stalder M, Eckstein FS, Englberger L. Deleterious outcome of No-React-treated stentless valved conduits after aortic root replacement: why were warnings ignored? J Thorac Cardiovasc Surg. 2008;136(1):52-57.

73. Dellgren G, Eriksson MJ, Brodin LA, Rådegran K. Eleven years' experience with the Biocor stentless aortic bioprosthesis: clinical and hemodynamic follow-up with long-term relative survival rate. Eur $J$ Cardiothorac Surg. 2002;22(6):912-921.

74. Grande KJ, Cochran RP, Reinhall PG, Kunzelman KS. Mechanisms of aortic valve incompetence: finite element modeling of aortic root dilatation. Ann Thorac Surg. 2000;69(6):1851-1857.

75. Sripathi VC, Kumar RK, Balakrishnan KR. Further insights into normal aortic valve function: role of a compliant aortic root on leaflet opening and valve orifice area. Ann Thorac Surg. 2004;77(3): $844-851$.
Research Reports in Clinical Cardiology

\section{Publish your work in this journal}

Research Reports in Clinical Cardiology is an international, peerreviewed, open access journal publishing original research, reports, editorials, reviews and commentaries on all areas of cardiology in the clinic and laboratory. The manuscript management system is completely online and includes a very quick and fair peer-review system.

\section{Dovepress}

Visit http://www.dovepress.com/testimonials.php to read real quotes from published authors. 